\title{
ENTREPRENEURIAL ACTIVITIES IN TURKEY: AN INTERNATIONAL COMPARISON USING GEM DATA*
}

\author{
ESRA KARADENIZ** \\ Yeditepe University
}

\author{
ÖZLEM ÖZDEMIR YILMAZ**** \\ Middle East Technical University
}

\begin{abstract}
The purpose of this study is to explore the entrepreneurial activities in Turkey and to determine Turkey's entrepreneurial position globally. Data is collected through the standard survey of the Global Entrepreneurship Monitor (GEM) project. The results indicate a low participation rate of women and young individuals in the entrepreneurial activities and a low level of entrepreneurial dynamism in the Turkish economy. Furthermore, lack of financial support, inadequate government policies providing knowledge about technology and tax incentives, and insufficient intellectual property rights are found to be some of the important obstacles encountered by entrepreneurs in Turkey compared to those in some developing and developed countries.
\end{abstract}

Key words: entrepreneurship, Global Entrepreneurship Monitor Data, small and medium-sized enterprises, Turkey.

\section{TÜRKIYE'DE GIRIŞIMCILIIK FAALIYETLERİ: GEM VERISİ KULLANARAK ULUSLARARASI BIR KARŞILAŞTIRMA}

\author{
$\ddot{O Z E T}$
}

Bu çalışmanın amacı Türkiye'deki girişimcilik faaliyetlerini açıklamak ve Türkiye’nin girişimcilik bakımından uluslararası yerini belirlemektir. Veriler, Global Girişimcilik İzleme (GEM) projesinde kullanılan standart anket aracılı̆̆ıyla toplanmıştır. Sonuçlar, Türkiye ekonomisinde kadınların ve gençlerin girişimcilik faaliyetlerine katılım oranlarının ve girişimciliğ̈in dinamizm seviyesinin düşük olduğunu göstermektedir. Bunun yanında, bazı gelişmekte ve gelişmiş ülkelerle kıyaslandı ̆̆ında, Türkiye'deki girişimcilerin finansal destek yokluğu, teknoloji ve vergi destekleri konusunda bilgi veren uygun devlet politikalarının olmayışı ve eksik fikri mülkiyet haklarının varlığı gibi sorunlarla karşılaştı ̆̆ı ortaya çıkmaktadır.

Anahtar kelimeler: girişimcilik, Global Girişimcilik İzleme Verisi, küçük ve orta ölçekli işletmeler, Türkiye.

* The authors thank the GEM Project team for their initiative contribution, and Siemens and Technical Development Association of Turkey for their financial support.

** Esra Karadeniz is an Assistant Professor in the Department of Economics at Yeditepe University, Inönü Mahallesi, Kayışdağı Caddesi, 34755, Kadıköy, Istanbul, Turkey. E-mail: ekaradeniz@ yeditepe.edu.tr

***ÖZlem Erdemir Yilmaz is an Associate Professor in the Department of Business Administration at Middle East Technical University, İnönü Bulvarı, 06531, Ankara, Turkey. E-mail: yozlem@ metu.edu.tr 
Entrepreneurial behavior within existing organizations has mostly been defined in the literature as the activities in which individuals use innovative resources to generate opportunities (Mair, 2002: 1). Most previous work has shown that the innovative focus of entrepreneurship is an important factor of the economic and social development (e.g., Acs and Audretsch, 1993; Drnovsek, 2004; Tang and Koveos, 2004; Wennekers et al., 2005). The important contributions of entrepreneurs in accelerating the economic growth of a developing country like Turkey go hand-in-hand with the contributions of small and medium-sized enterprises (SMEs). SMEs represent more than $99 \%$ of the total number of Turkish enterprises in the manufacturing sector (KOSGEB, 2005).

"The entrepreneur, being a founder, a transformer, a producer, and a reproducer of the organization with its norms and values," is a central and vital factor that affects the existences of SMEs (Yetim and Yetim, 2006). The success of a small business depends on the initiatives of the individual entrepreneur to create a viable business. Therefore, a nationwide study of the general behavior of entrepreneurs and the environmental factors that motivate them to embark on an entrepreneurial career is crucial. Accordingly, the purpose of the current study is to (1) explore the entrepreneurial behavior of Turkish entrepreneurs based on demographic and sector-based differences, (2) identify the perceived legal and economic environment for entrepreneurship in Turkey, and (3) provide information about where Turkey stands in the global business environment in terms of its entrepreneurial activities.

The paper contributes to the entrepreneurship literature in many aspects. First, we have collected data through the standard questionnaire designed by the Global Entrepreneurship Monitor (GEM) ${ }^{(1)}$ research program. GEM has been an ongoing academic project designed to collect data annually on the entrepreneurial behavior of 42 countries. Turkey joined the GEM project for the first time in 2006. We report findings from the original 2006 GEM database. ${ }^{(2)}$ Note that the GEM data is exceptionally well suited to make international comparisons. Although firm-level studies about small businesses in Turkey exist (e.g., Alpkan et al., 2007; Kozan et al., 2006; Müslümov et al., 2005; Özcan, 1995), to our knowledge, the current study is the first attempt to investigate specifically entrepreneurial activities in Turkey and to compare the nationwide environment for entrepreneurship with those of other countries.

Second, in the previous literature, "entrepreneurial activity" has been defined as "any attempt to create a new business enterprise or to expand an existing business by an individual, a team of individuals, or an established business" (Reynolds et al., 2005). Based on that, we have determined the percentage of entrepreneurs in Turkey, and further we have classified them as either early-stage entrepreneurs (ESE) or established entrepreneurs (EE). The early stage entrepreneurs are adults who are actively involved in either starting or managing a business they wholly or partly own which is less than three and a half years old. The established entrepreneurs are adults who own and manage a business that pays wages or salaries for more than 42 months. Early-stage entrepreneurship indicates the dynamic entrepreneurial propensity of a country. In other words, it shows the percentage of the population that is willing and able to undertake an entrepreneurial venture. Established entrepreneurship, on the other hand, indicates the percentage of the population actively involved in running businesses that have proved to be sustainable (Bosma and Harding, 2006). Our study is the first attempt that provides information separately about each type of entrepreneurship in Turkey.

Third, the environment for entrepreneurship is important for new firm creation (e.g., Chow, 2006; Begley et al., 2005). Entrepreneurial decisions differ depending on the environment in which they are taken (e.g., McGrath et al., 1992; Smallbone and Welter, 2001). For instance, Wennekers et al. (2005) argue that technology, level of economic development, culture, and existing institutions influence 
the demand for entrepreneurship by creating opportunities for start-ups. Therefore, as we explore the entrepreneurship in Turkey, we put specific emphasis on understanding how Turkish entrepreneurs perceive their environment.

Finally, it is a well-known fact that entrepreneurship varies widely across nations (e.g., Masuda, 2006). However, most studies have explored the relevant determinants of entrepreneurship for only one nation (e.g., Freytag and Thurik, 2007; Grilo and Irigoyen, 2006; Parker, 2004). As mentioned by Davidsson and Magnus (2002: 81), "cross-country differences in the degree of productive entrepreneurial activity are likely candidates for explaining part of the observed cross-country differences in economic performance." Hence, through identifying Turkey's place in the world with respect to its entrepreneurial activities, we tend to partially explain its comparative economic performance.

\section{LITERATURE REVIEW}

Entrepreneurship is a multidimensional phenomenon spanning different units of observation that range from individual to firm, region, industry, and even to nation (Wennekers et al., 2005). Due to this nature, conceptual and theoretical approaches to understanding why some individuals start new businesses have built on a variety of disciplines such as economics, sociology, and psychology. In the current study, we try to explore the demographic characteristics of entrepreneurs in Turkey and compare them with other countries. Based on an eclectic framework of the determinants of the entrepreneurship, Verheul et al. (2005), distinguishing between the demand and supply side of entrepreneurship, have shown the importance of socio-demographic factors such as age, income, work status, and education in explaining the entrepreneurial behavior. For instance, several studies have shown that there is a significant difference in the entrepreneurial participation rate between males and females (e.g., Allen et al., 2007, Minniti et al., 2006, Minniti, 2005). Likewise, while some studies find that the relationship between the education level and the likelihood of becoming an entrepreneur is not strictly linear (Minniti and Bygrave, 2004; Minniti, 2005), others find education to be an important factor for fostering the entrepreneurship in some countries such as The People's Republic of China (Chow, 2006), Belgium, and Finland (Arenis and Minniti, 2005). Moreover, the early entrepreneurial activity rates are found to be relatively low among 18-24 year olds, peak among 25-34 year olds, and then decline sharply for those above 44 (Minniti et al., 2006). Bosma and Herding (2007) further report that early stage entrepreneurs in developing countries are mostly in the 25-34 age groups, whereas in the developed countries they are usually in the 35-44 age groups.

The industrial analyses of the entrepreneurship in a country have been investigated looking at the distribution of sales among each sector, export intensity, and degree of innovation (newness of products offered to customers, intensity of competition, and usage rate of new technology). Sector distribution is categorized as: extractive sectors (agriculture, forestry, fishing, and mining); transformative sectors (construction, manufacturing, and transportation); business services (the customer is another business); and consumer services (restaurants, health, education, social services, and recreation). Accordingly, the previous literature has found that ESEs do business mostly in the consumer-oriented sector in the developing countries, while they are involved in the business-oriented sector in the developed countries (Bosma and Harding, 2007). Exports have several advantages for economic advancement of which the most obvious one is the gains related to scale and scope economies (Kogut, 1985; Grant et al., 1988) from larger volumes of sales and production resulting in revenue growth. As the number of exporting entrepreneurs increase, their revenues increase, easing long existence of the business in the industry and increasing the trade openness of the nation. As Gardner (1994) argued, "entrepreneurial 
behavior is based on vision and focuses on innovation." Many entrepreneurs are important agents of innovations (Venkataraman, 1997). Established firms have more financial means and knowledge to invent and/or improve products or services (Ahuja and Lampert, 2001). According to the literature, no matter what a country's average level of per capita income is, customer-oriented innovation is relatively rare (Minniti et al., 2006).

Finally, the environment for entrepreneurship is important for new firm creation (Chow, 2006; Begley, et al., 2005). Entrepreneurial decisions can be different because of the effects of the environment in which they are taken (e.g., McGrath, et al., 1992; Smallbone and Welter 2001). Wennekers et al., (2005) argue that technology, the level of economic development, culture, and institutions all influence the demand for entrepreneurship by creating opportunities available for start-ups. We explore the environment for entrepreneurship in Turkey and compare it with the other developed and developing countries based on 15 conditions that are considered to have a direct impact on the entrepreneurial climate, according to the GEM project. These are: (1) availability of financial support, (2) appropriateness of government policies, (3) adequacy of government programs, (4) conduciveness of education and training, (5) efficacy of research and development transfer, (6) availability and costeffectiveness of commercial and professional infrastructure, (7) extent of internal market openness, (8) quality and accessibility of physical infrastructure, (9), supportiveness of culture, (10) opportunities for new venture creation, (11) entrepreneurial capacity, (12) attitude towards entrepreneurship, (13) intellectual property rights, (14) perceived population composition, and (15) high growth firms.

\section{THE SMALL BUSINESS ENVIRONMENT IN TURKEY}

Small and medium-sized enterprises (SMEs) constitute a major part of the Turkish economy, accounting for a large proportion of the country's businesses and total employment. In the year 2000, the SME sector accounted for $99.8 \%$ of the total number of enterprises, $76.7 \%$ of total employment, $38 \%$ of capital investment, $26.5 \%$ of value added, roughly $10 \%$ of exports, and $5 \%$ of bank credits in Turkey (KOSGEB report, 2005). Therefore, while SMEs dominate the economy in terms of employment, they evidently operate with comparatively little capital equipment, generate relatively low levels of value added, make only a small contribution to Turkish exports and receive only a marginal share of the funds mobilized by the banking sector. In the manufacturing sector, while $77.3 \%$ of the wage earners are male, only $22.7 \%$ are female. The average age of enterprises in the manufacturing sector is 9.1 years.

SMEs are usually family businesses and do not have regular employees. The average number of people employed is 4.8 and they are distributed across industries as follows: metallic goods: $26.1 \%$, textiles, clothing and leather goods: $25.6 \%$, wood and furniture: $24.3 \%$, food and drink: $12.7 \%$, paper: $3.9 \%$, other sectors: $7.4 \%$ (KOSGEB report, 2005).

The export-led growth strategy in the 1980s stimulated the productivity and exports increased until the Russian and Asian crises and the İzmit earthquake in 1999. The financial problems in the banking sector, the low rate of foreign investment, and the slowness of the applications of privatization policies put the Turkish economy into big economic crises in November 2000 and in February 2001. As a result, the interest rates increased, the Turkish Lira devalued, and the flexible exchange was instituted. SMEs found themselves in a different legal and economic environment. The government decreased the direct export subsidies because of the big budget deficit and many sectors were threatened by 
their competitors in Asia. Facing all of these obstacles, SMEs realized the need to find ways to increase productivity. In fact, the value-added, the export shares and investments of high-tech products increased, indicating a movement in the manufacturing sector from low tech to medium tech products (TEPAV, 2007).

There are many problems that prevent the international competitiveness of Turkey from being sustainable. First of all, $84 \%$ of the investments in innovation are for buying new machines and equipments while only 5\% are for skilled labor, 7\% are for Research and Development, and 2\% are for getting licenses, which indicate that SMEs are mainly using existing technology. The legal rights of the Turkish shareholders/owners index are half of those in OECD and European countries, indicating the lack of a trustworthy legal environment (World Bank, 2005). The tax rates and prices for telecommunication and energy sectors and credit histories for SMEs prevent most financial institutions providing financial support.

\section{DATA AND METHODOLOGY}

We used standard questionnaires of the $\mathrm{GEM}^{(3)}$ to collect information about the demographic characteristics of SMEs' managers and how they perceived their institutional and legal environment. The data collection method consisted of two parts: an adult population survey (APS), and a national expert survey (NES) (Reynolds et al., 2005). The first data were collected using the national adult population survey (APS) from the Global Entrepreneurship monitor (GEM) project (Reynolds et al., 2005). A representative sample of 2417 adults, aged 18-64, in 19 cities in Turkey ${ }^{(4)}$ was interviewed using a standard GEM questionnaire. A random Sampling Method was used and a CATI (Computer Assisted Telephone Interview) was conducted by the vendor company. ${ }^{(5)}$ Data used in this paper was collected in 2006 when Turkey joined the project for the first time.

In the APS part, we first classified individuals as "entrepreneurs" versus "non-entrepreneurs" according to the definitions of early-stage and established entrepreneurs. Accordingly, out of 2417 respondents only 147 individuals matched the definition of early-stage entrepreneurs, and 278 individuals were found to be established entrepreneurs. The rest were basically non-entrepreneurs. Then we presented APS questions about the demographic characteristics and the sectors' characteristics to both types of "entrepreneurs," namely EEs and ESEs.

As the second data collection method, a questionnaire (NES) that contained 82 questions concerning the assessment of the situation with regard to the entrepreneurial framework conditions (EFC) was asked in face to face interviews with 36 experts. ${ }^{(6)}$ We explored how Turkish "entrepreneurs" perceive the environment for entrepreneurship in Turkey and compared it with the other countries' entrepreneurs' perceptions based on 15 conditions that were considered to have a direct impact on the entrepreneurial climate. The degree of the presence of each condition was measured by taking the average of the experts' responses to 5 point Likert-scale questions ( 1 indicates strong disagreement and 5 indicates strong agreement to existence of the explained environment in Turkey).

The data allowed us to make cross-national comparisons of the entrepreneurial activities between Turkey and some developing and developed countries which participated in the GEM project in 2006. Fourteen developing countries were chosen for comparison: India, Jamaica, Indonesia, Philippines, Peru, Colombia, Brazil, Chile, Thailand, Mexico, Uruguay, Malaysia, South Africa, and Argentina. 
Twenty-one developed countries were listed as Slovenia, Greece, Spain, Singapore, Italy, France, Sweden, United Kingdom, Germany, Netherlands, Japan, Belgium, Australia, Finland, Canada, Denmark, Iceland, United States of America, Ireland, Norway, and United Arab Emirates. ${ }^{(7)}$

\section{RESULTS}

There is evidence that the relationship between income per capita and entrepreneurial activity is not linear (Bosma and Harding, 2007). Figure 1 shows per capita income in US dollars on the horizontal axis against the Total Early-Stage Entrepreneurial Activity (ESE) rate (the percentage of ESEs, in the adult population) on the vertical axis. This provides evidence of a U-shaped relationship between entrepreneurial activity and income per capita. Entrepreneurial activity is highest among the poorest countries, but appears to decline as income per capita increases to between 25-35,000 US dollars. Thereafter, however, there is some evidence that entrepreneurial activity rises as income per capita rises above 30,000 US dollars.

Figure 1

Total Early-Stage Entrepreneurial Activity (ESE) by Economic Development and Fitted Parabolic Trend: Year 2006

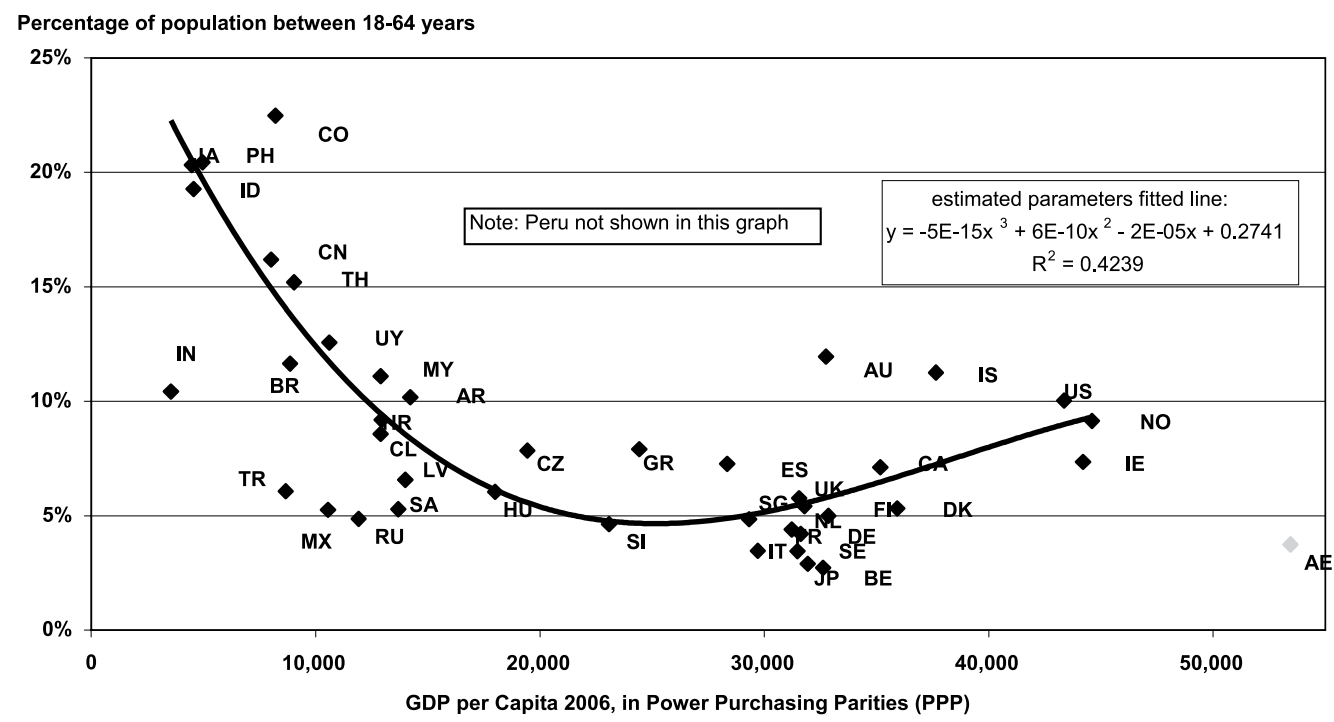

Source: Bosma and Harding (2007)

Note: The figure shows per capita in income in US dollars on the horizontal axis against the Total Early-Stage Entrepreneurial Activity (ESE) rate (the percentage of ESE in the adult population) on the vertical axis. The early stage entrepreneurs are adults who are actively involved in either starting or managing a business they will wholly or partly own, which is less than three and a half years old. TR stands for Turkey.

Turkey is classified as a middle-income developing country with an approximately 8,663 US dollars per capita income in Purchasing Power Poverty. Given that, we put Turkey on the lower left side of the curve based on the data collected in the current study. Turkey has a lower ESE rate than the expected 
rate for a country with the same level of per capita income. It is interesting to note that Turkey shares a similar entrepreneurial position with Mexico, Russia, and South Africa. Russia and South Africa have emerged from a past where entrepreneurial activity had been suppressed by the prevailing legal and political systems. Entrepreneurial activity had been illegal under the former socialist system in Russia, and blacks had been suppressed under the apartheid system in South Africa.

\section{Entrepreneurial Activity and Demographics}

The average ESE rate is estimated to be $6.07 \%$ in Turkey, meaning that only 147 of 2417 individuals are found to be early stage entrepreneurs. This rate is significantly lower than the one for the developing countries, $14.16 \%$ (chi-square $=124.44$, $\mathrm{p}$-value $=0.00$ ), but it is not different from the average rate of the developed countries, $6.09 \%$ (chi-square $=0.000256$, p-value $=0.98$ ). This is consistent with the U-shaped relationship between income and entrepreneurial activity in different countries depicted in Figure 1. However, in terms of established entrepreneurs, the average Established Entrepreneurship Activities (EE) rate (the percentage of EE in the total adult population) of Turkey is found to be much higher than that of both developing countries, 9.93\% (chi-square $=6.0912$, $p$-value $=0.0135$ ) and developed countries, $6.3 \%$ (chi-square $=106.7324$, p-value $=0.000)$. One possible explanation may be that Turkish government attention and support have always been more favorable to large firms than small firms (Kurtuluş, 1987).

It is important to note that the ratio of ESE to EE rate is 1.03 for developed countries, 0.67 for developing countries, and 0.53 for Turkey. This relatively low level of early stage entrepreneurship activity in Turkey can be interpreted as the lack of entrepreneurial dynamism, which may be problematic for Turkey's endeavors for economic growth while at the same time indicating a lack of competitive pressure on the established businesses to increase their productivity.

The demographic characteristics of Turkish EE and ESE are presented in Table 1. Observe the malefemale rate of participation in the early stage entrepreneurial activities is 2.42 in Turkey, which is almost twice the male-female ESE rates in both the developing countries (1.26), and the developed countries (1.64). The male participation rate in established entrepreneurial activity is even more clear. The age distribution of Turkish early stage entrepreneurs (who are mostly between 25 and 34 yearsold) presented in Table 1 is similar to those in most developing countries. EEs, however, are mostly 35-44 years old, which is similar to the age structure in both developed and developing countries in the sample.

Remarkably, the number of people with post-secondary degrees or graduate school experience involved in early-stage entrepreneurial activity in developing (just over 31 entrepreneurs out of every 100 adults), and developed countries (29 entrepreneurs out of every 100 adults), is much more than that of Turkey (6 entrepreneurs out of every 100 adults). However, this dramatic cross-national difference does not exist for the education level of established business entrepreneurs (established business owners that have post secondary or graduate degree are 17 entrepreneurs out of every 100 adults for developing countries, 26 entrepreneurs for developed countries, and 16 entrepreneurs for Turkey). Finally, regarding income levels, the data indicate that Turkish people with higher incomes are more likely to be involved in entrepreneurial activity than their counterparts in other nations. Further, when compared with the other developing countries, the percentage of EE among high-income earners is much higher in Turkey. 
Table 1

Entrepreneurial Activity and Demographics (\% in ESE and EE)

\begin{tabular}{|c|c|c|c|}
\hline & TURKEY & $\begin{array}{l}\text { DEVELOPING } \\
\text { COUNTRIES }\end{array}$ & $\begin{array}{l}\text { DEVELOPED } \\
\text { COUNTRIES }\end{array}$ \\
\hline \multicolumn{4}{|l|}{ GENDER } \\
\hline ESE (male) & 71 & 56 & 60 \\
\hline ESE (female) & 29 & 44 & 40 \\
\hline ESE : Male/Female Ratio & 2.42 & $\begin{array}{l}1.26 * \\
(12.99,0.000)\end{array}$ & $\begin{array}{l}1.72 * \\
(7.27,0.007)\end{array}$ \\
\hline EE: (male) & 74 & 62 & 68 \\
\hline $\mathrm{EE}$ (female) & 26 & 38 & 32 \\
\hline EE: Male/Female Ratio & 2.77 & $\begin{array}{l}1.66 * \\
(15.68,7.5 \mathrm{E}-05)\end{array}$ & $\begin{array}{l}2.11 * \\
(4.44,0.003)\end{array}$ \\
\hline \multicolumn{4}{|l|}{ AGE } \\
\hline ESE: Age category $18-24$ & 14.3 & 17.54 & 15.00 \\
\hline ESE: Age category 25-34 & 44.7 & $\begin{array}{l}35.11 * \\
(22.76,1.84 \mathrm{E}-06)\end{array}$ & $\begin{array}{l}\text { 33.66* } \\
(26.2,3.07 \mathrm{E}-07)\end{array}$ \\
\hline ESE: Age category 35-44 & 27.2 & 25.68 & 34.78 \\
\hline ESE: Age category 45-54 & 11.1 & 14.64 & 26.55 \\
\hline ESE: Age category 55-64 & 2.66 & 7.03 & $\begin{array}{l}16.84 * \\
(30.8,2.7 E-08)\end{array}$ \\
\hline EE: Age category $18-24$ & 6.66 & 6.28 & 12.01 \\
\hline EE: Age category 25-34 & 27.4 & 22.45 & 19.44 \\
\hline EE: Age category $35-44$ & 34 & 31.45 & 33.99 \\
\hline EE: Age category 45-54 & 20.7 & 26.30 & 38.80 \\
\hline EE: Age category 55-64 & 11.2 & 13.53 & $\begin{array}{l}27.75 * \\
(3.6,0.0002)\end{array}$ \\
\hline \multicolumn{4}{|l|}{ EDUCATION LEVEL } \\
\hline ESE: some secondary degree & 5.87 & $\begin{array}{l}12.29 * \\
(5.6,0.017)\end{array}$ & $\begin{array}{l}11.14 * \\
(3.9,0.047)\end{array}$ \\
\hline ESE: secondary degree & 7.5 & 15.07 & 12.09 \\
\hline ESE: post-secondary degree & 4.26 & 16.03 & 14.53 \\
\hline ESE: graduate experience & 2.23 & $\begin{array}{l}15.01 * \\
(28.61,8.84 E-08)\end{array}$ & $\begin{array}{l}15.12 * \\
(27.9,9.03 E-08)\end{array}$ \\
\hline EE: some secondary degree & 13.7 & 10.37 & 11.57 \\
\hline EE: secondary degree & 9.13 & 9.04 & 11.68 \\
\hline EE: post-secondary degree & 8.65 & 9.17 & 13.34 \\
\hline EE: graduate experience & 8.1 & 8.60 & 13.79 \\
\hline \multicolumn{4}{|l|}{ INCOME LEVEL } \\
\hline ESE: lowest household 33 ptile & 1.93 & $\begin{array}{l}9.98 * \\
(16.43,5.03 E-05)\end{array}$ & $\begin{array}{l}10.48 * \\
(12.8,4,05 E-05)\end{array}$ \\
\hline ESE: middle household 33 ptile & 4.41 & 11.83 & 10.80 \\
\hline ESE: highest household 33 ptile & 7.1 & 10.39 & 11.92 \\
\hline EE: lowest household 33 ptile & 6.52 & 6.25 & 9.51 \\
\hline EE: middle household 33 ptile & 8.6 & 8.55 & 11.11 \\
\hline EE: highest household 33 ptile & 10.7 & 8.75 & 12.10 \\
\hline
\end{tabular}




\section{Entrepreneurial Activity and Sector-based Characteristics}

First, it is important to note that, as presented in Table 2, our data confirm the SME employment sizes indicated in prior research suggesting that over $80 \%$ of both the early stage and the established entrepreneurs employ five people or less.

Next, consistent with the studies involving other nations, the greatest numbers of Turkish early stage entrepreneurs are found to be doing business in the consumer-oriented services sector (46\%), followed by manufacturers in the transformative sector (34\%). According to the chi-square tests, the percentage of ESEs businesses in Turkey in both extractive and transforming sectors do not significantly differ from those in developing and developed countries. Interestingly, however, both early-stage and established entrepreneurship in business-oriented services are found to be relatively lower in Turkey than those in developed countries. The low rate of ESEs in business oriented services in Turkey, while being substantially lower in developed countries, appears to be a common characteristic of all developing countries in the sample. Finally, the percentage of EEs doing business in the extractive sector is found to be twice as much as those in both developing and developed countries. This figure is particularly important because it indicates the concentration of established Turkish entrepreneurs in manufacturing businesses (rather than services).

Table 2

Entrepreneurial Activity and Sectors (\% in ESE and EE)

\begin{tabular}{lccl}
\hline SECTORS & TURKEY & $\begin{array}{l}\text { DEVELOPING } \\
\text { COUNTRIES }\end{array}$ & $\begin{array}{l}\text { DEVELOPED } \\
\text { COUNTRIES }\end{array}$ \\
\hline ESE- Extractive sector & 8.02 & 5.53 & 7.92 \\
& & $(1.85,0.17)$ & $(0.012,0.91)$ \\
ESE-Transforming sector & 34.4 & 34.34 & 30.21 \\
& & $(8.6 \mathrm{E}-06,0.9)$ & $(0.985,0.32)$ \\
ESE-Business oriented services & 12 & 8.55 & $\mathbf{2 7 . 3 8}$ \\
& & $(2.44,0.12)$ & $\mathbf{( 1 6 . 6 9 5 , 4 . 3 9 E 0 5 )}$ \\
ESE-Consumer oriented services & 45.6 & 51.58 & 41.76 \\
& & $(2.04,0.15)$ & $(0.86,0.35)$ \\
EE-Extractive sector & 32.9 & $\mathbf{1 0 . 7 3} *$ & $\mathbf{1 6 . 0 8} *$ \\
& & $(\mathbf{1 1 . 0 , 2 . 0 9 E}) \mathbf{2 6})$ & $\mathbf{( 5 4 . 4 5 , 1 . 5 9 E - 1 3 )}$ \\
EE-Transforming sector & 29.7 & 35.17 & 34.46 \\
& & $(3.334,0.068)$ & $(2.676,0.10)$ \\
EE-Business oriented services & 5.35 & 7.54 & $\mathbf{2 4 . 7 5 *}$ \\
& & $(1.78,0.181)$ & $\mathbf{( 5 5 , 1 . 1 E - 1 3 )}$ \\
EE-Consumer oriented services & 32.1 & 46.56 & 32.82 \\
& & $(21.6,8.28 \mathrm{E}-06)$ & $(0.078,0.779)$ \\
\hline
\end{tabular}

The chi-square and p-values for the differences in the proportions test is presented in the parentheses.

*The proportion is significantly ( $\mathrm{p} \leq 0.05$ level) different than the proportion for Turkey.

ESE refers to early stage entrepreneurs and EE refers to established entrepreneurs. 
Table 3

Entrepreneurial Activity and Sector-based Characteristics (\% in ESE and EE)

\begin{tabular}{|c|c|c|c|}
\hline & TURKEY & $\begin{array}{l}\text { DEVELOPING } \\
\text { COUNTRIES }\end{array}$ & $\begin{array}{l}\text { DEVELOPED } \\
\text { COUNTRIES }\end{array}$ \\
\hline \multicolumn{4}{|l|}{ Export Intensity (Number of customers) } \\
\hline ESE: no customers outside country & 60.2 & $\mathbf{7 1 . 0 9}(8.48,0.003)^{*}$ & $42.34(18,2.14 \mathrm{E}-05)^{*}$ \\
\hline ESE: $1-25 \%$ of customers outside country & 22.5 & $17.79(2.09,0.147)$ & $42.16(22,1.62 \mathrm{E}-06) *$ \\
\hline ESE: $26-75 \%$ of customers outside country & 7.49 & $7.09(0.03,0.85)$ & $14.61(5.9,0.015)^{*}$ \\
\hline ESE: $76-100 \%$ of customers outside country & 9.89 & $4.03(11.8,0.00)^{*}$ & $11.94(0.59,0.44)$ \\
\hline EE: no customers outside country & 72.2 & $73.67(0.28,0.59)$ & $45.06(79,5.3 \mathrm{E}-19) *$ \\
\hline EE: $1-25 \%$ of customers outside country & 19 & $19.53(0.04,0.82)$ & $42.31(60,9.7 \mathrm{E}-15)^{*}$ \\
\hline EE: $26-75 \%$ of customers outside country & 4.58 & $4.37(0.02,0.87)$ & $15.18(24,1.0 \mathrm{E}-06)^{*}$ \\
\hline EE: $76-100 \%$ of customers outside country & 4.26 & $2.44(3.2,0.07)$ & $9.34(8.36,0.000)^{*}$ \\
\hline \multicolumn{4}{|l|}{ Newness of products offered to customers } \\
\hline ESE: product new to all customers & 34.1 & $20.23(16,5.03 \mathrm{E} 05) *$ & $18.89(21.4,11 \mathrm{E}-06)^{*}$ \\
\hline ESE: product new to some customers & 31.3 & $30.40(0.05,0.81)$ & $35.65(1.19,0.27)$ \\
\hline ESE: product new to no customers & 34.6 & $49.38(12,0.00)^{*}$ & $54.89(24,1.14 \mathrm{E}-06)^{*}$ \\
\hline EE: product new to all customers & 43.2 & $19.10(88,6.77 \mathrm{E}-21)^{*}$ & $14.88(160,1.3 \mathrm{E}-36)^{*}$ \\
\hline EE: product new to some customers & 26.7 & $23.88(1,0.3)$ & $23.71(1.2,0.26)$ \\
\hline EE: product new to no customers & 30.1 & $57.02(74,6.9 \mathrm{E}-18)^{*}$ & $71.31(215,9.4 \mathrm{E}-49)^{*}$ \\
\hline \multicolumn{4}{|l|}{ Intensity of Competition } \\
\hline ESE: Many businesses offer same product & 72.2 & $55.93(15,0.00)^{*}$ & $54.81(17,3 \mathrm{E}-05)^{*}$ \\
\hline ESE: Few businesses offer same product & 24.6 & $35.12(7,0.00)^{*}$ & $40.60(15,8,1 \mathrm{E}-05)^{*}$ \\
\hline ESE: No businesses offer same product & 3.12 & $8.95(6,0.01)^{*}$ & $14.96\left(16,6.1 \mathrm{E}-05^{*}\right.$ \\
\hline EE: Many businesses offer same product & 75.8 & $69.36(5,0.02)^{*}$ & $67.05(9.3,0.00)^{*}$ \\
\hline EE: Few businesses offer same product & 23.4 & $25.43(0.56,0.45)$ & $33.07(11,0.00)^{*}$ \\
\hline EE: No businesses offer same product & 0.83 & $5.21(11,0.00)^{*}$ & $10.72(29,7.8 \mathrm{E}-08 *$ \\
\hline \multicolumn{4}{|l|}{ Usage Rate of New Technology } \\
\hline $\begin{array}{l}\text { ESE: Uses very latest technology (only } \\
\text { available since last year) }\end{array}$ & 1.32 & $14.44(20,6.8 \mathrm{E}-06)^{*}$ & $15.03(21,3.6 \mathrm{E}-06)^{*}$ \\
\hline ESE: Uses new technology ( 1 to 5 years) & 14.4 & $22.48(5.3,0.02)^{*}$ & $23.97(7,0.006)^{*}$ \\
\hline ESE: Uses no new technology & 84.3 & $63.08(28,1.32 \mathrm{E} 07)^{*}$ & $72.32(10,0.001)^{*}$ \\
\hline $\begin{array}{l}\text { EE: Uses very latest technology (only } \\
\text { available since last year) }\end{array}$ & 2.47 & $5.55(4.7,0.03) *$ & $11.35(21.5,3.5 \mathrm{E} 06)^{*}$ \\
\hline EE: Uses new technology ( 1 to 5 years) & 8.14 & $14.92(9,0.002)^{*}$ & $14.85(9.68,0.001)^{*}$ \\
\hline EE: Uses no new technology & 89.4 & 79.53(15.6,7.7E05)* & $85.59(3.1,0.07)$ \\
\hline
\end{tabular}

The chi-square and p-values for the differences in the proportions test is presented in the parentheses.

*The proportion is significantly ( $\mathrm{p} \leq 0.05$ level) different than the proportion for Turkey.

ESE refers to early stage entrepreneurs and EE refers to established entrepreneurs. 
Table 3 presents the sector-based characteristics of EE and ESE entrepreneurs' businesses. While the majority of the ESEs businesses (60.17\%) have no exports, $10 \%$ of them have more than $75 \%$ of their customers in export markets (Table 3). It appears that, proportionately, ESEs have more customers outside Turkey than EEs. The results further indicate that entrepreneurs in Turkey are more export oriented than entrepreneurs in other developing countries. This could be the result of the export-led policy that has been applied since the 1980s.

In order to measure innovation, we asked entrepreneurs how they evaluate the newness of their product or service, the competition they face, and the novelty of their technology. Thirty-four percent of ESEs and $43 \%$ of EEs claim that they offer products that are new to all customers. Probably established firms have more financial means and knowledge to invent and/or improve products or services (Ahuja and Lampert, 2001). According to the literature, no matter what a country's average level of per capita income is, customer-oriented innovation is relatively rare (Minniti et al., 2006). However, according to our findings, Turkey's level of customer-oriented innovation is unusually high compared to international standards. Turkish entrepreneurs think that their products and/or services are new for their customers although these products may not be new in the international markets.

As for the intensity of competition, almost $75 \%$ of ESEs and EEs in Turkey state that there are many businesses offering the same product as theirs, indicating much higher perceptions of competitive intensity than the developing and developed countries in the sample. Furthermore, the percentages of the EEs and ESEs in Turkey indicating that their product is unique in the industry are very low, $0.83 \%$ and $3.12 \%$ respectively. These findings indicate that Turkish entrepreneurs compete highly by offering the same products, using strategies other than product differentiation or invention strategies.

Finally, "technological innovation in production" is important for lowering production costs and meeting changing consumer needs (Saka-Helmhout and Karabulut, 2006). The majority of Turkish entrepreneurs state that they do not use new technology. The average usage of the latest technology is $1.32 \%$ by ESEs and $2.47 \%$ by EEs. These rates are less than the technology usage rates of the entrepreneurs in other developing countries.

\section{Environment for Entrepreneurial Activities}

Table 4 presents the perceptions of Turkish experts about the framework conditions for entrepreneurship. Financial support (the accessibility to financial resources), government support policies (priority given to new firms in public procurement tenders), and government programs (required permits and licenses within a week and the amount of taxes) are stated as the conditions that are perceived to exist less than in the other countries in the sample.

Next, although the Turkish government supports the implementation of the anti-bureaucracy program, the evidence from the expert questionnaire confirms that the protection of intellectual property is relatively problematic in Turkey compared to the developed countries. As in the case of other developing countries, the Turkish education system seems to provide little entrepreneurship orientation compared to the education systems in the developed countries. The experts' responses further show that the commercial and professional infrastructure in Turkey, again while being similar to those in other countries' standards, appears to be relatively worse in comparison to developed countries. The commercial and professional infrastructure is the physical structure that supports entrepreneurial activities. For example, the communication structure that includes quality and ease of access to 
telecommunication tools (telephone, internet, etc.) is part of these evaluations. In depth interviews with the experts further suggest that access to telecommunication services is relatively unproblematic in Turkey, and yet these services are found to be extremely costly.

Table 4

Overview of Entrepreneurial Framework Conditions

\begin{tabular}{|c|c|c|c|}
\hline $\begin{array}{l}\text { Entrepreneurial Framework } \\
\text { Conditions }\end{array}$ & TURKEY & $\begin{array}{l}\text { DEVELOPING } \\
\text { COUNTRIES }\end{array}$ & $\begin{array}{l}\text { DEVELOPED } \\
\text { COUNTRIES }\end{array}$ \\
\hline Financial support & 1.76 & $\begin{array}{l}2.40 \\
(-1.079,0.33)\end{array}$ & $\begin{array}{l}2.97 * \\
(-6.7,0.001)\end{array}$ \\
\hline $\begin{array}{l}\text { Government regulation \& support } \\
\text { policies }\end{array}$ & 1.9 & $\begin{array}{l}2.21 \\
(0.189,0.86)\end{array}$ & $\begin{array}{l}2.86 * \\
(6.47,0.01)\end{array}$ \\
\hline Government programs & 2.05 & $\begin{array}{l}2.31 \\
(1.016,0.356)\end{array}$ & $\begin{array}{l}2.94 * \\
(-3.24,0.02)\end{array}$ \\
\hline R\&D transfer & 2.14 & $\begin{array}{l}2.16 \\
(0.64,0.55)\end{array}$ & $\begin{array}{l}2.70 \\
(-2.13,0.086)\end{array}$ \\
\hline $\begin{array}{l}\text { Education and training, primary \& } \\
\text { secondary }\end{array}$ & 2.36 & $\begin{array}{l}2.4 \\
(-2.1,0.086)\end{array}$ & $\begin{array}{l}2.57 * \\
(-3.15,0.025)\end{array}$ \\
\hline Intellectual Property Rights & 2.4 & $\begin{array}{l}2.47 \\
(-2.5,0.064)\end{array}$ & $\begin{array}{l}3.52 * \\
(-5.5,0.005)\end{array}$ \\
\hline $\begin{array}{l}\text { Ease of entry \& } \\
\text { market openness }\end{array}$ & 2.95 & $\begin{array}{l}2.675 \\
(0.96,0.38)\end{array}$ & $\begin{array}{l}2.875 \\
(0.82,0.45)\end{array}$ \\
\hline Entrepreneurial capacity & 2.51 & $\begin{array}{l}2.59 \\
(0.3,0.77)\end{array}$ & $\begin{array}{l}2.85 \\
(1.6,0.18)\end{array}$ \\
\hline High growth firms & 2.53 & $\begin{array}{l}2.78 \\
(-0.64,0.56)\end{array}$ & $\begin{array}{l}3.33 \\
(-2.22,0.09)\end{array}$ \\
\hline National culture & 2.78 & $\begin{array}{l}2.80 \\
(-1.7,0.15)\end{array}$ & $\begin{array}{l}3.06 \\
(-0.26,0.8)\end{array}$ \\
\hline $\begin{array}{l}\text { Commercial and professional } \\
\text { infrastructure }\end{array}$ & 2.85 & $\begin{array}{l}3.02 \\
(-1.7,0.16)\end{array}$ & $\begin{array}{l}3.50 * \\
(-2.8,0.049)\end{array}$ \\
\hline Population composition & 2.9 & $\begin{array}{l}3.21 \\
(-1.7,0.16)\end{array}$ & $\begin{array}{l}3.49 \\
(-2.28,0.085)\end{array}$ \\
\hline $\begin{array}{l}\text { Opportunities for new venture } \\
\text { creation }\end{array}$ & 3.18 & $\begin{array}{l}3.47 \\
(-2.7,0.06)\end{array}$ & $\begin{array}{l}3.50 \\
(-1.25,0.28)\end{array}$ \\
\hline Access to physical infrastructure & 3.32 & $\begin{array}{l}3.50 \\
(1.1,0.33)\end{array}$ & $\begin{array}{l}4.02 \\
(-0.88,0.425)\end{array}$ \\
\hline Attitude towards entrepreneurship & 3.69 & $\begin{array}{l}3.54 \\
(1.7,0.16)\end{array}$ & $\begin{array}{l}3.52 \\
(1.7,0.15)\end{array}$ \\
\hline
\end{tabular}

The t-statistics and the p-values to compare the mean values are presented in parentheses.

*The mean value is significantly ( $\mathrm{p} \leq 0.05$ level) different than the mean value for Turkey.

Note that the numbers represent the mean values of the experts' responses to 5-Likert scale questions asked about each condition, where 1 indicates strong disagreement and 5 indicates strong agreement to whether the explained entrepreneurial framework condition exists in Turkey. 
Despite all these unfavorable conditions for entrepreneurial activity, the experts' perceptions regarding ease of entry and market openness, opportunities for new venture creation, the population of youth in the population, and general attitudes towards entrepreneurship are very favorable. In fact, the scores for these conditions are not significantly different from those of the developed countries. We believe the existence of these conditions may indicate that Turkey has a good potential to provide a favorable environment for new small businesses.

\section{DISCUSSIONS AND CONCLUSION}

The present study is the first attempt to explore the entrepreneurial activities in Turkey at the individual level. Turkey has taken part in the General Entrepreneurship Monitor Data (GEM) project for the first time in 2006, making the data used in this study original and exceptionally well suited for international comparisons.

Our finding about the business structure of entrepreneurship is consistent with the SME structure in Turkey. The results show that the early-stage entrepreneurial rate is low in Turkey, whereas the level of the established business entrepreneurship rate is reasonable. In fact, as Kurtuluş (1987) suggests, big and family-owned companies appear to dominate the business environment in Turkey. More important, the relatively lower level of ESEs indicated in the findings may suggest that entrepreneurial dynamism, which is crucial for nationwide innovativeness and competitiveness, is problematic in Turkey (Bullvaag et al., 2006: 9).

The low participation of females and younger individuals in entrepreneurial activities in most countries is even more observable in Turkey, thus emphasizing the necessity of finding incentives to encourage these people to become entrepreneurs. In order to increase the participation of females and younger individuals in entrepreneurial activities, there is a need to improve vocational training programs to equip students with technical skills and foster entrepreneurial attitudes in young minds. The low participation rate of females in entrepreneurial activities may in fact be a direct reflection of the low participation rate of women in the labor force in Turkey. A number of recent studies show that the lack of work-family reconciliation mechanisms and gender roles stand as the strongest obstacles in front of women in Turkey and create supply side bottlenecks for them to become participants in the labor market (İlkkaracan and Acar, 2007).

Supporting the claim of Bosma and Harding (2007), ESEs mostly do business in the consumer-oriented services sector in Turkey. Most EEs, however, are found to be in the extractive manufacturing sector. This supports the TEPAV (Turkish Economic Policy Research Foundation) report (2007) concluding that the manufacturing sector in Turkey is shifting gradually from low tech to medium tech products. The percentage of both early-stage and established entrepreneurs in the business-oriented services sector is relatively lower than in the other countries. In fact, the business-to-business phenomenon in general is relatively new in Turkey.

The percentage of Turkish early entrepreneurs that have most of their customers outside the country is higher than those in the other developing countries. This may be the result of the export-led policy that has been applied since the 1980s. It appears that Turkish entrepreneurs remain competitive in the international arena despite the boom in international competition and the real currency appreciation since 2003 which threatened the Turkish exports. 
Next, the intensity of competition in the Turkish business environment is also found to be comparably very high relative to other nations. Turkish entrepreneurs appear to use less differentiation and invention strategies. This contrasts sharply with the Turkish entrepreneurs' perception that they are highly innovative with respect to the products and services they offer to their customers. In fact, the data suggest that a large number of firms in the Turkish market place offer exactly the same product to the customers and that most entrepreneurs use updated, established technology. For policy suggestions to encourage innovativeness, it is crucial to reveal the barriers to the innovative decisions of SMEs in Turkey. The protection of intellectual property rights is frequently cited as one of the basic reasons for problems in the area of the transfer of science and technology (Demirbaş, 2006).

Availability of finance is also an important factor in facilitating entrepreneurial activity, especially in the early stages of a new venture. The provisions of equity and finance, venture capital and initial public offering (IPO) in Turkey are quite poor. Founders of new firms depend largely on their own or on their family's savings. Many entrepreneurs are unaware of the various forms of state financial support available to them. Small businesses encounter difficulties when they borrow money from the banks because of (a) the high interest rates, the high costs of loan guarantees, and the short repayment terms offered; (b) the extensive documentation requirements and the amount of time it takes for banks to process applications; and (c) the banks' preferences for the large firms.

Another important inhibitor of entrepreneurial activity is the complexity of access to government programs aimed at supporting entrepreneurs, compounded with the very poor marketing of these programs. The firms cannot obtain government assistance from one single agency and furthermore the type of assistance that is available is not necessarily adequate. The Turkish government has established the Enterprise Development Centre for new and growing firms, but not only is their number limited, also they are not sufficiently integrated within the local environment.

In sum, this study concludes that although there are many obstacles encountered by Turkish entrepreneurs (such as an inadequate government Research and Development policy, insufficient intellectual property rights, lack of information concerning technology, and a lack of financial sources), the positive attitudes of society towards entrepreneurship and the existence of market openness to rapid change signal that there is always new potential for entrepreneurs in Turkey.

\section{NOTES}

1. Detailed information about the GEM project can be found at www.gemconsortium.org

2. One of the authors involved in the data collection process.

3. Authors can provide the questionnaires upon request.

4. The names of cities and the sampling sizes for each city in the brackets are: Istanbul (444), Ankara (202), İzmir (156), Adana (100), Samsun (100), Gaziantep (100), Erzurum (100), Denizli (100), Diyarbakır (100), Malatya (100), Konya (100), Trabzon (100), Antalya (100), Bursa (115), Kahramanmaraş (100), Manisa (100), İçel (100), Kayseri (100), Kocaeli (100). 
5. The vendor company is Akademetre which has ISO 9000-2001 quality certification, and is a member of European Society of Opinion, Marketing Researchers (ESOMAR), Turkish Association of Marketing, and Opinion Researchers. It has an honor agreement with Association of Researchers.

6. Turkish Experts include "professionals" (e.g. venture capitalists, academics, bankers, consultants, politicians), and "entrepreneurs" (they are selected primarily on the basis of their active entrepreneurial experience in Turkey).

7. The country classification is based on the World Economic Outlook Database, 2006.

\section{REFERENCES}

Acs, Z.J. and Audretsch D.B. (1993). Small Business and Entrepreneurship: An East-West Perspective, Cambridge: Cambridge University Press.

Ahuja, G., and Lampert C.M. (2001). "Entrepreneurship in the Large Corporation: A Longitudinal Study of How Established Firms Create Breakthrough Inventions," Strategic Management Journal, 22(6/7): 521-543.

Allen, I.E., Langowitz, N., and Minniti, M. (2007). “Global Entrepreneurship Monitor: 2006.” Report on Women and Entrepreneurship, The Centre for Women's Leadership, Babson Park, M.A.: Babson College and London, U.K.: London Business School.

Alpkan, L., Yılmaz, C., and Kaya, N. (2007). "Market Orientation and Planning Flexibility in SMEs: Performance Implications and an Empirical Investigation," International Small Business Journal, 25(2): 152-172.

Arenius, P., and Minniti, M. (2005). "Perceptual Variables and Nascent Entrepreneurship," Small Business Economics, 24: 233-247.

Begley, T.M., Tan, W.L., and Schoch, H. (2005). "Politico-Economic Factors Associated with Interest in Starting a Business: A Multi-Country Study," Entrepreneurship Theory and Practice, 29(1): 35-55.

Bosma, N. and Harding, R. (2007). "Global Entrepreneurship: GEM 2006 Summary Results.” Babson Park, M.A.: Babson College and London, U.K.: London Business School.

Bullvaag, E., Acs, Z.J., Allen, I.E., Bygrave, W.D., and Spinelli, S. Jr. (2006). "GEM-United States 2004-2005." Executive Report, Babson Park, M.A.: Babson College and London, U.K.: London Business School.

Chow, I.H. (2006). "The Relationship between Entrepreneurial Orientation and Firm Performance in The People's Republic of China,” Advanced Management Journal, 71(3): 11-20.

Davidsson P. and Magnus, H. (2002). "Determinants of the Prevalence of Start-ups and High-Growth Firms," Small Business Economics, 19(2): 81-104. 
Demirbaş, D. (2006). "New Institutional Economy and Innovation Barriers: Micro Econometric Evidence," The Business Review, 5: 82-88.

Drnovsek, M. (2004). "Job Creation Process in a Transition Economy," Small Business Economics, 23: $179-188$.

Freytag, A. and Thurik R (2007). "Entrepreneurship and Its Determinants in a Cross-Country Setting," Journal of Evolutionary Economics, 17(2): 117-131.

Gardner, D.M. (1994). "Marketing-Entrepreneurship Interface: A Conceptualisation,” in G.E. Hills (ed.), Marketing and Entrepreneurship: Research Ideas and Opportunities: 35-54. Westport, CT: Quorum Books.

Grant, R.M., Jamine, A.P., and Thomas, H. (1988). "Diversity, Diversification, and Profitability among British Manufacturing Companies, 1972-1984," Academy of Management Journal, 31: 771781.

Grilo, I. and Irigoyen, J.M. (2006). "Entrepreneurship in the EU: to wish and not to be," Small Business Economics, 26(4): 305-318.

İlkkaracan, İ. and Acar, S. (2007). "Institutional and Social Determinants of Female Labor Force Participation in Turkey: Who Cares Determines Who is in the Labor Force and Who is not." IAFFE 2007 Annual Conference Proceedings, available on the web.

Kogut, B. (1985). "Designing Global Strategies: Profiting from Operational Flexibility,” Sloan Management Review, 27(1): 27-38.

KOSGEB (Small and Medium Industry Development Organization), (2005). “Turkey-Germany,” XI. Period Cooperation, Council Meeting, Berlin. Available [on line] at: www.bdi-online.de/Dokumente/ Internationale-Maerkte/DTKR_KOSGEE.pdf

Kozan, M.K., Oksoy, D., and Özsoy, O. (2006). "Growth Plans of Small Businesses in Turkey," Journal of Small Business Management, 44(1): 114-129.

Kurtuluş, K. (1987), “Entrepreneurship in Turkey,” Journal of Small Business Management, 25(4): 66-69.

Mair, J. (2002). "Entrepreneurial Behavior in a Large Traditional Firm: Exploring Key Drivers " Research paper No.466, IESE. Barcelona: University of Navara.

Masuda, T. (2006). "The Determinants of Latent Entrepreneurship in Japan," Small Business Economics, 26(3): 227-240.

McGrath, R.G. and MacMillan, I.C. (1992). "More Like Each Other than Anyone Else?: CrossCultural Study of Entrepreneurial Perceptions," Journal of Business Venturing, 7(5): 419-429. 
Minniti, M. and Bygrave, W.D. (2004). "Global Entrepreneurship Monitor: 2003.” Babson Park, M.A.: Babson College and London, U.K.: London Business School.

Minniti, M. (2005). "An Empirical Assessment of Entrepreneurial Behavior: The Case of Italy," Global Business and Economics Review, 7(1): 31-46.

Minniti, M., Bygrave, W.D., and Autio, E. (2006). "Global Entrepreneurship Monitor: 2005." Executive Report, London, U.K.: London Business School and Babson Park, MA.: Babson College.

Müslümov, A., Güler, A., and Cenktan, O. (2005). "Macroeconomic Stabilization Programs and Financial Performance of Small and Medium Sized Enterprises in Turkey," Journal of International Business and Entrepreneurship, 11(1): 19-40.

Özcan, G. (1995). "Small Business Networks and Local Ties in Turkey," Entrepreneurship and Regional Development, 7: 265-82.

Parker, S.C. (2004). The Economics of Self-Employment and Entrepreneurship. Cambridge: Cambridge University Press.

Reynolds, P., Bosma, N., Autio, E., Hunt, S., Bono, N.D., Servais, I., Lopez-Garcia, P., and Chin, N. (2005). "Global Entrepreneurship Monitor: Data Collection Design and Implementation, 1998-2003," Small Business Economics, 24: 205-231.

Saka-Helmhout, A and Karabulut, E. (2006). "Institutional Barriers to Entrepreneurship in Clusters: Evidence from the Turkish Textile Sector," International Journal of Emerging Markets, 1(2): 128146.

Smallbone, D. and Welter, F. (2001). "The Distinctiveness of Entrepreneurship in Transition Economies," Small Business Economics, 16(4): 249-262.

Tang, L., and P.E. Koveos (2004). "Venture Entrepreneurship, Innovation Entrepreneurship, and Economic Growth,” Journal of Developmental Entrepreneurship, 9(2): 161-171.

TEPAV (2007). “Türkiye'nin Rekabet Gücü için Sanayi Politikası Çerçevesi,” Ekonomi Etütleri, 1 Temmuz 2007. Available [on line] at: www.tepav.org.tr

Venkataraman, S. (1997). “The Distinctive Domain of Entrepreneurship Research: an Editor's Perspective," in J. Katz and R. Brockhaus (eds.), Advances in Entrepreneurship Firm Emergence and Growth: 119-138. Greenwich, CT: JAI Press.

Verhaul, I., Uhlaner, L., and Thurik, R. (2005). "Business Accomplishments, Gender and Entrepreneurial Self-Image," Journal of Business Venturing, 20: 483-518.

Wennekers, S., Uhlaner, L.M., and Thurik R. (2002). "Entrepreneurship and Its Conditions: A Macro Perspective," International Journal of Entrepreneurship Education, 1: 25-64 
Wennekers, S., Stel, A., and Reynolds, P. (2005). "Nascent Entrepreneurship and the Level of Economic Development," Small Business Economics, 24(3): 293-309.

World Bank. (2005). Doing Business 2006: Creating Jobs. Washington, DC.

Yetim, N. and Yetim, U. (2006). "The Cultural Orientations of Entrepreneurs and Employees Job Satisfaction: The Turkish Small and Medium Sized Enterprises (SMEs) Case," Social Indicators Research, 77: 257-286 